\title{
Latex agglutination test for detection of Australia antigen (HB-Ag) among blood donors and patients
}

\author{
R. HOPKINS AND P. C. DAS \\ From the South-East Regional Blood Transfusion Service, Royal Infirmary, Edinburgh
}

SUMmARY The application of the latex test for the detection of Australia antigen (Au-Ag) was investigated. Reagents from two commercial sources were compared with the electrophoresis method with regard to sensitivity and specificity using samples from blood donors, hospital patients, and plasma fractions. Discordant results were further investigated by electron microscopy and radioimmunoassay.

Differences were noted in the results between these reagents and the significance of the findings together with suggestions for minimizing false positive results are discussed.

The introduction of a latex agglutination test for the detection of Au-Ag (HAA/HB-Ag) by Leach and Ruck (1971), which can be read in minutes and is claimed to be as sensitive as the generally recognized counter immunoelectroosmophoresis technique, may be regarded as an important advance. This report describes our experience with this technique applied to blood donors and patients and compares it with the counter immunoelectroosmophoresis method. Electron microscopy and radioimmunoassay were performed on those specimens showing consistent discrepancy between the results by counter immunoelectroosmophoresis and latex agglutination.

\section{Materials and Methods}

STANDARD SERA

Known $\mathrm{Au}-\mathrm{Ag}$ positive serum and plasma samples from our reference panel were collected either locally or from abroad including the reference panel no. 2 of the Department of Biologics Standard, NIH (Bethesda, Maryland), and the American Red Cross (Washington). Serum and plasma taken into different anticoagulants (citrate, oxalate, heparin, and EDTA) from nine healthy males (39-64 years) were tested both serologically including radioimmunoassay, and by electron microscopy for use as negative controls. Further, a group of sera selected from the panel that had been tested by different laboratories (by multiple methods) and giving concordant results, were used in this study as positive and negative controls (table I).

\section{TEST SAMPLES}

Test samples were obtained from several sources: from plasmaphoresis donors, from known contacts to $\mathrm{Au}-\mathrm{Ag}$, from miscellaneous patients including some with rheumatoid arthritis, and from coagulation factor concentrates prepared by the Scottish National Plasma Fractionation Centre. Also, 10 known $\mathrm{Au}-\mathrm{Ag}$ positive sera were derived from the screening, by counter immunoelectroosmophoresis, of 15000 donors. Of these $10 \mathrm{Au}-\mathrm{Ag}$ positive sera, four were subtyped as ad + and a further four as ay + by Le Bouvier (1971) at Yale University; all 10 were coded and randomly dispersed among the other test samples.

\section{LATEX AGGLUTINATION TEST}

Two separate batches (PF1, PF2) of latex particles coated with anti-Au-Ag, prepared in guinea-pigs and supplied by Pfizer Ltd, ${ }^{1}$ were tested according to the method of Leach and Ruck (1971). A further set of reagents (anti-Au-Ag prepared in rabbits) was also supplied by Hoechst Pharmaceuticals Ltd, ${ }^{2}$ and the tests were performed as recommended by the manufacturers. By the same procedure further tests were carried out using latex tagged with normal rabbit IgG and with guinea-pig immunoglobulin (obtained commercially from Wellcome Reagents ${ }^{2}$ 


\begin{tabular}{|c|c|c|c|c|c|}
\hline $\begin{array}{l}\text { Samples with }\left(^{(*)} \text { or }\right. \\
\text { Without }\left({ }^{\circ}\right) A u-A g\end{array}$ & Latex Pfizer (2) & Latex Hoechst & $\begin{array}{l}\text { Counter Immuno- } \\
\text { electroosmophoresis }\end{array}$ & $\begin{array}{l}\text { Electron } \\
\text { Microscopy }\end{array}$ & $\begin{array}{l}\text { Radio- } \\
\text { immunoassay }\end{array}$ \\
\hline${ }^{\circ} \mathbf{A}$ & + & + & - & - & - \\
\hline$\approx \mathbf{B}$ & + & - & + & - & + \\
\hline${ }^{\circ} \mathrm{C}$ & - & - & - & - & - \\
\hline *D & + & + & + & + & + \\
\hline E & + & + & + & + & + \\
\hline${ }^{\circ} \mathbf{F}$ & - & - & - & - & - \\
\hline${ }^{*} \mathbf{G}$ & + & + & + & + & + \\
\hline${ }^{\circ} \mathrm{H}$ & - & - & - & - & - \\
\hline${ }^{\circ} \mathbf{I}$ & - & - & - & - & - \\
\hline ○J & - & - & - & - & - \\
\hline$* \mathbf{K}$ & + & + & + & + & + \\
\hline$* \mathbf{L}$ & + & + & + & - & + \\
\hline${ }^{\circ} \mathbf{M}$ & - & - & - & - & - \\
\hline${ }^{\circ} \mathbf{N}$ & - & - & - & - & - \\
\hline$* 0$ & + & + & + & - & + \\
\hline${ }^{\circ} \mathbf{P}$ & - & - & - & - & - \\
\hline Q & + & + & + & + & + \\
\hline${ }^{\circ} \mathbf{R}$ & - & - & - & - & - \\
\hline
\end{tabular}

Table I Coded reference panel samples tested by radioimmunoassay, two different preparations of latex, and other methods

and Pfizer Ltd). The results were scored as + for strong, \pm for weak, and - for no agglutination.

\section{OTHER METHODS}

Counter immunoelectroosmophoresis was performed by the modification of Das, Hopkins, Cash, and Cumming (1971) and read after tannic acid treatment (Hopkins and Das, 1972).

Basic electron microscopy and immune electron microscopy were performed as described by Kelen, Hathaway, and McLeod (1971). Solid phase radioimmunoassay using radioiodinated marker, antiAustralia antigen 1251(Austria-125), obtained from the Abbott Laboratories ${ }^{1}$, was used in accordance with the manufacturer's directions.

\section{Results}

Preliminary studies on the various latex preparations set up against known standard $\mathrm{Au}-\mathrm{Ag}$ positive sera demonstrated that although all apparently reacted satisfactorily, differences in sensitivity could be shown between the reagents (table II). Further, the 10 positive sera derived from routine screening of ${ }^{1}$ Queenborough, Kent, UK.

\begin{tabular}{|c|c|c|c|}
\hline \multirow{2}{*}{$\begin{array}{l}\text { Counter- } \\
\text { Immunoelectro- } \\
\text { osmophoresis }\end{array}$} & \multicolumn{3}{|l|}{ Latex } \\
\hline & Pfizer Batch 1 & Pfizer Batch 2 & Hoechst \\
\hline $1: 16$ & $1: 4$ & $1: 256(1: 512)^{1}$ & $1: 4$ (t) \\
\hline
\end{tabular}

Table II Comparative antigen titration with different batches of latex and by counter immunoelectroosmophoresis

'Figures in parenthesis are before addition of normal animal serum.
15000 blood donors, when tested with one batch of latex (PF1), all reacted strongly; four of these which were subtyped ad + had a mean reaction time of 1.9 minutes (range 0.8-2.5 minutes) and four which were subtyped ay + had a mean reaction time of 2.8 minutes (range $1 \cdot 5-4 \cdot 5$ minutes).

Based on these findings 100 selected test samples were set up against the PF2 and Hoechst latex preparations. The results are summarized in table III; all samples shown to be positive by counter immunoelectrophoresis were also strongly positive with the PF2 latex preparation. However, the Hoechst material failed to detect one out of six of the Au-Agpositive samples, and both the latex preparations produced five false positives.

As the one false negative reaction occurred in a serum from a patient, a further 10 patients' sera were tested. These sera were kindly supplied by the Edinburgh University Department of Bacteriology's diagnostic service and were tested against the PF2 and Hoechst reagents. The results are summarized in table IV which shows that the PF2 reagent detected all six Au-Ag positive sera. However, the Hoechst latex preparation reacted to only two of these sera. Both reagents gave false positive reactions all of which were also negative to electron microscopic and immune electron microscopic examination. Prior heat treatment of these sera $\left(56^{\circ} \mathrm{C}\right.$ for 30 minutes) did not influence the non-specific latex agglutinin titre, except in one sample out of the six so treated, and the addition of normal guinea-pig serum to the test as recommended by one manufacturer produced false negative result in a haemophiliac (table IV), probably due to physical dilution. However, in all of these sera the presence of non- 


\begin{tabular}{|c|c|c|c|c|}
\hline \multirow[t]{2}{*}{ Source } & \multirow{2}{*}{$\begin{array}{l}\text { No. of Samples } \\
\text { Tested }\end{array}$} & \multicolumn{3}{|l|}{ Number of Positives } \\
\hline & & $\begin{array}{l}\text { Counter Immuno- } \\
\text { electroosmophoresis }\end{array}$ & $\begin{array}{l}\text { Latex } \\
\text { Pfizer II }\end{array}$ & $\begin{array}{l}\text { Latex } \\
\text { Hoechst }\end{array}$ \\
\hline $\begin{array}{l}\text { Plasmaphoresis subjects } \\
\text { Coagulation disorders } \\
\text { Plasma fraction (DEF-IX) } \\
\text { Carrier (Au-Ag) blood donor } \\
\text { Contacts and staff } \\
\text { Transplant donors } \\
\text { Alcoholic liver } \\
\text { Myeloma } \\
\text { Normal sera }\end{array}$ & $\begin{array}{r}65 \\
9 \\
4 \\
5 \\
11 \\
8 \\
2 \\
1 \\
1 \\
2\end{array}$ & $\begin{array}{l}0 \\
1 \\
0 \\
0 \\
5 \\
0 \\
0 \\
0 \\
0 \\
0\end{array}$ & $\begin{array}{l}0 \\
1 \\
1 \\
2 \\
5 \\
0 \\
1 \\
0 \\
1 \\
0\end{array}$ & $\begin{array}{l}3 \\
0 \\
1 \\
1 \\
5 \\
0 \\
0 \\
0 \\
0 \\
0\end{array}$ \\
\hline Total & 100 & 6 & 11 & 10 \\
\hline
\end{tabular}

Table III Tests by two different latex reagents on 100 selected specimens and comparison with counterimmunoelectroosmophoresis

\begin{tabular}{|c|c|c|c|c|c|}
\hline \multicolumn{2}{|c|}{ Clinical Diagnosis } & \multirow{3}{*}{$\begin{array}{l}\text { Counterimmuno- } \\
\text { electroosmophoresis } \\
(\times 5 \text { Conc. Sera) }\end{array}$} & Without & Wit & \multirow{3}{*}{$\begin{array}{l}\text { Hoechst } \\
\text { Latex }\end{array}$} \\
\hline & & & \multicolumn{2}{|c|}{ Pfizer Latex (2) } & \\
\hline & & & \multicolumn{2}{|c|}{ Normal Guinea-pig Sera } & \\
\hline $\mathrm{J} 6703$ & Diabetis & - & + & + & - \\
\hline J5821 & Serum jaundice & + & + & + & - \\
\hline $\mathrm{J} 6566$ & Chronic myeloid leukaemia & - & - & - & - \\
\hline $\mathrm{J} 6477$ & Haemophilia & + & + & - & + \\
\hline $\mathrm{J} 6508$ & Haemophilia & + & + & + & - \\
\hline J6655 & Aplastic anaemia & + & + & + & - \\
\hline J6046 & Obstructive jaundice & + & + & + & + \\
\hline $\mathrm{J} 6018$ & After bypass & 一 & - & 一 & - \\
\hline J5979 & Haemophilia & + & + & + & - \\
\hline J5983 & Obstructive jaundice & - & - & - & + \\
\hline
\end{tabular}

Table IV Results obtained on patients' sera using Pfizer and Hoechst latex agglutination test

specific latex agglutinins could be readily demonstrated by latex-coated normal rabbit or guinea-pig immunoglobulins.

In order to ascertain whether this latter observation could be used in monitoring false positive results, sera from 19 patients with rheumatoid arthritis (seven of whom were positive for rheumatoid factor) were tested with rabbit anti-Au-Ag coated latex (Hoechst) and with normal rabbit immunoglobulin sensitized latex (Wellcome Reagents). Table $\mathrm{V}$ shows that nine samples were negative to both preparations, one serum showed a weak positive reaction to anti-Au-Ag coated latex only, but a further nine samples reacted to both specific and non-specific latex reagents; the agglutination titres against the specific anti-Au-Ag coated latex (mean $24 \pm 23$ ) and non-specific gamma globulin-coated latex $(13 \pm 11)$ showed highly significant correlation $(r=0.91, P<0.001)$ in the later group of nine sera. All 19 samples were negative by counter immunoelectrophoresis.

Attempts to reduce further the time required for the latex technique by using plasma instead of serum

\begin{tabular}{llll}
\hline $\begin{array}{l}\text { Number of } \\
\text { Samples }\end{array}$ & $\begin{array}{l}\text { Anti-Au- } \\
\text { coated } \\
\text { Latex }\end{array}$ & $\begin{array}{l}\text { Normal Rabbit } \\
\text { Gamma Globulin- } \\
\text { coated Latex }\end{array}$ & $\begin{array}{l}\text { Counter- } \\
\text { immuno- } \\
\text { electro- } \\
\text { osmophoresis }\end{array}$ \\
\hline 9 & - & - & - \\
9 & + & + & - \\
1 & \pm & - & - \\
\hline
\end{tabular}

Table V Sera from rheumatoid arthritis patients tested by normal rabbit gamma globulin-coated latex and anti-Au-sensitized latex (Hoechst)

proved disappointing. Fresh normal plasma, irrespective of the anticoagulant used, produced weak but definite latex agglutination and heat treatment $\left(56^{\circ} \mathrm{C}\right.$ for 30 minutes) did not modify this reaction. Sera from the same donors (tested after two hours at $37^{\circ} \mathrm{C}$ ) were negative.

In a further investigation, radioimmunoassay was used in parallel with both preparations of antiAu-Ag-coated latex (Hoechst and Pfizer). Positive and negative specimens from the Reference Panel were coded and tested by a variety of other methods. 
Table I shows that all the eight known positive samples were correctly identified by radioimmunoassay, counter immunoelectroosmophoresis, and Pfizer latex (PF2). However, one remained negative with the Hoechst reagent and three with electron microscopy. No false positive results were obtained by radioimmunoassay, counter immunoelectroosmophoresis, and electron microscopy, but one occurred with both specific latex reagents. This was confirmed by negative results obtained by these three techniques.

\section{Discussion}

The surprising feature of this study was the good agreement between both the latex preparations and the counter immunoelectroosmophoresis technique when applied to sera obtained from known $\mathrm{Au}-\mathrm{Ag}$ positive blood donors. On the other hand undoubted false negatives occurred in sera obtained from $\mathrm{Au}-\mathrm{Ag}$ positive patients with the Hoechst and PF1 preparations. This may have been due to a limited specificity of the coating antibody, for preliminary studies in this laboratory have suggested that the antigen typed as ay + may not react as effectively as those designated ad + with the latex reagents we used. It seems more likely, however, that the problem, which is of some clinical importance, may be more closely related to the low sensitivity of these reagents. This conclusion is supported by the absence of false negatives with the PF2 preparation.

False positive reactions to both the latex reagents used in this study have been reported previously (Banatvala, Best, Almeida, and Dane, 1971; Cossart, Field, March, and Porter, 1972; Burrell, Dickson, Gerber, McCormick, and Marmion, 1972) and our results confirm these observations. In investigating the proficiency of anti-Au-Ag coated latex, Perkins, Perkins, Chen, and Vyas (1972) noted about 2.5 times higher false positivity amongst hospital samples compared with those from normal volunteer donors, and while using basically a similar latex agglutination principle for the detection of rheumatoid factor, Caplan (1963) noted a very high degree of reactivity amongst the non-rheumatoid patients compared with blood donors. The increased reactivity in patients' sera may reflect the presence of substances such as rheumatoid factor, heterophil antibody, or species specific substances, whose diverse properties may affect comparisons between normal individuals and patients (Hoq, Cash, Das, and Cumming, 1971). In addition Langenhuysen (1971) demonstrated the presence of antibodies against gamma globulin causing agglutination in the latex fixation test in patients following transfusions and cytomegalovirus infection. One factor respons- ible for these non-specific reactions in some sera seems to be associated with the IgM fraction (Zalan, Wilson, and Labzoffsky, 1972), for three out of five rheumatoid sera which agglutinated both specific and non-specific latex reagents became negative following mercaptoethanol treatment (table V).

With regard to the false positive results, none of the preparations tested appeared to have any advantage over the others. The fact that different latex preparations react falsely with different $\mathrm{Au}$ - Agnegative sera may reflect differences in animal species from which the immunoglobulins were derived, and in the methods of coating the latex, all of which may influence the primary structure of the immunoglobulin molecule (Stanworth and Pardoe, 1967).

To eliminate this problem heating at $56^{\circ} \mathrm{C}$ for 30 minutes has been claimed to be effective (Ziegenfuss, 1972), but this was not confirmed by our experience. However, our findings do suggest that latex coated with appropriate normal immunoglobulin introduced as 'control' would help to identify spurious positive results, although simultaneous presence of $\mathrm{Au}-\mathrm{Ag}$ and non-specific agglutinin(s) could cause agglutination of both 'test' and 'control' reagents. Since the positive $\mathrm{Au}-\mathrm{Ag}$ sera gave $85 \%$ agreement between the two manufacturers' reagents tested, this approach might be useful for emergency screening, provided that the reagents are of high quality and sensitivity; the result, however, is available in about five minutes and repeating the test after an absorption procedure with appropriate normal gamma globulin-coated latex could augment the specificity of this reaction. The simplicity and short length of time involved in the latex test for detecting $\mathrm{Au}-\mathrm{Ag}$ appear to make it an ideal reagent for rapid monitoring of purification stages of $\mathrm{Au}-\mathrm{Ag}$ containing materials, and this approach has been successfully employed as one of the methods for standardization of the antigen for sensitizing human red cells employed in a passive haemagglutination test (Hopkins and Das, 1973) for detection of $\mathrm{Au}-\mathrm{Ag}$ and its antibody.

We are grateful to Drs R. A. Cumming and J. D. Cash for constant help and encouragement, to Dr George L. Le Bouvier of the Department of Epidemiology and Public Health, Yale University School of Medicine, for the subtyping study, to Professor B. P. Marmion of the Department of Bacteriology, Edinburgh University, for electron microscopy, to Mr J. M. Leach of Pfizer Ltd, and to Mr D. Evans of Hoechst Pharmaceuticals, for a generous supply of latex agglutination kits. Tests for rheumatoid factor were carried out by $\mathrm{Dr} M$. S. Hoq. 


\section{References}

Banatvala, J. E., Best, J. M., Almeida, J. D., and Dane, D. M. S. (1971). Latex agglutination test for Australia antigen. Brit. med. J., 4, 814 .

Burrell, C. J., Dickson, J. D., Gerber, H., McCormick, J. N., and Marmion, B. P. (1972). Rheumatoid arthritis, rheumatoid factor and tests for Australia or hepatitis-associated antigen. Brit. med. J., 4, 23-24.

Caplan, H. I. (1963). The use of latex fixation tests in non-rheumatic states. Ann. intern. Med., 59, 449-453.

Cossart, Y. E., Field, A. M., March, S. P., and Porter, A. A. (1972). Latex test for Au-antigen. Lancet, 2, 379.

Das, P. C., Hopkins, R., Cash, J. D., and Cumming, R. A. (1971). Rapid identification of hepatitis associated antigen and antibody by counter-immunoelectroosmophoresis. Brit. J. Haemat., 21, 673-676.

Hopkins, R., and Das, P. C. (1972). Improved sensitivity of the electrophoresis method by tannic acid for detection to Australia antigen. J. clin. Path., 25, 832-833.

Hopkins, R., and Das, P. C. (1973). A tanned cell haemagglutination test for the detection of hepatitis associated antigen (Au-Ag) and antibody (anti-Au). Brit. J. Haemat., 25, 619629.

Hoq, M. S., Cash, J. D., Das, P. C., and Cumming, R. A. (1971).
Variability of sheep red cells in their reaction to agglutinins in normal human sera. Brit. J. Haemat., 21, 677-681.

Kelen, A. E., Hathaway, A. E., and McLeod, D. A. (1971). Rapid detection of Australia/SH antigen and antibody by a simple and sensitive technique of immunoelectron microscopy. Canad. J. Microbiol., 17, 993-1000.

Langenhuysen, M. M. A. C. (1971). Antibodies against $\gamma$-globulin after blood transfusion and cytomegalovirus-infection. Clin. exp. Immunol., 9, 393-398.

Leach, J. M., and Ruck, B. J. (1971). Detection of hepatitis associated antigen by the latex agglutination test. Brit med. $J, 4,597-598$.

Le Bouvier, G. L. (1971). The heterogeneity of Australia antigen. $J$. infect. Dis., 123, 671-675.

Perkins, H. A., Perkins, S. L., Chen, E., and Vyas, G. N. (1972). A latex agglutination test for hepatitis associated antigen (HB-Ag). In Hepatitis and Blood Transfusion, edited by G. N. Vyas, H. A. Perkins, and R. Schmid, p. 181-187. Grune and Stratton, New York and London.

Stanworth, D. R., and Pardoe, G. I. (1967). Structure and biological characteristics of the immunoglobulins. In Handbook of Experimental Immunology, edited by D. M. Weir, p. 301. Blackwell, Oxford.

Zalan, E., Wilson, C., and Labzoffsky, N. A. (1972). Personal communication.

Ziegenfuss, J. F. Jr. (1972). Testing for Australia antigen. Brit. med. J., 2, 48 